\title{
TORNAR-SE OUTRO: A RECONFIGURAÇÃO DO SUJEITO LÍRICO NA POESIA DE ORIDES FONTELA
}

\author{
BECOME ANOTHER: THE RECONFIGURATION OF THE \\ LYRIC SUBJECT IN THE POETRY OF ORIDES FONTELA
}

\author{
Carlos Gledson Moreira Guedes ${ }^{1}$ \\ [https://orcid.org/0000-0003-4756-8640] \\ Paulo Benites ${ }^{2}$ \\ [https://orcid.org/0000-0002-5809-0956] \\ DOI: 10.30612/raido.v15i38.14853
}

\begin{abstract}
RESUMO: A presente análise debruça-se sobre o poema "Caramujo", da poeta brasileira Orides Fontela (1940-1998). O poema foi publicado em seu livro de estreia, Transposiçâo (1966-1967). A proposta deste ensaio éler o poema numa tentativa de cotejo e aproximaçâo com a tradiçâo brasileira na qual se pode reconhecer o que estamos pensando como a reconfiguraçăo do sujeito lírico. $O$ que há de comum nos poetas aqui escolhidos é uma tensăo no modo como o sujeito se apresenta, um estado limiar no qual se observa o nâo reconhecimento de si, uma negaçáo do eu, portanto, e a preocupaçâo em rejeitar uma projeçáo atravessada pelo externo de si. Trata-se, portanto, de poetas que constroem o "eumínimo", a metamorfose do sujeito em outros seres e coisas através da linguagem, de modo que éa palavra, a lida com a linguagem, que aparece em primeiro plano, e năo o eu lírico. Para fundamentar nossa leitura, retomamos a indagaçâo de Jacques Ranciére (2017) quanto a necessidade de repesarmos uma política do lirismo. O percurso metodológico construído propóe uma leitura crítica do poema da Orides Fontela e o cotejo entre os poetas a fim de levantarmos uma linhagem da tradiçăo da poesia brasileira contemporânea.
\end{abstract}

Palavras-chave: Eu lírico; sujeito; tradiçâo lírica; poesia brasileira contemporânea.

ABSTRACT: This analysis focuses on the poem "Caramujo", by the Brazilian poet Orides Fontela (1940-1998). The poem was published in her debut book, Transposiçâo (19661967). The purpose of this essay is to read the poem in an attempt to collate and approach the Brazilian tradition in which we can recognize what we are thinking as the reconfiguration of the lyric subject. What is common in the poets chosen here is a tension in the way the subject presents himself, a threshold state in which one observes the non-recognition of oneself, a denial of the self, therefore, and the concern to reject a projection crossed by the external of himself. It is, therefore, poets who build the "eumínimo", the metamorphosis of the subject in other beings and things through language, so that is the word, the deal with language, that appears in the foreground, and not the lyrical self. To support our reading, we return to the inquiry of Jacques Ranciére (2017) as to the need to reince us a policy of lyrism. The methodological path constructed

\footnotetext{
1 Universidade Federal de Rondônia

2 Universidade Federal de Rondônia
} 
proposes a critical reading of the poem of Orides Fontela and the comparison among poets in order to raise a lineage of the tradition of contemporary Brazilian poetry.

Keywords: Lyrical; subject; lyric tradition; contemporary Brazilian poetry.

\section{"[...] o poema é um caracol onde ressoa a música do mundo [...]" \\ Octavio Paz, O Arco e a Lira.}

\section{CONSIDERAÇÕES INICIAIS: A PROPOSIÇÃO DO PROBLEMA}

A análise desenvolvida neste texto dialoga abertamente com uma questăo que vem ganhando cada vez mais atençăo da crítica de poesia nessas primeiras duas décadas do Século XXI, qual seja, o lugar do sujeito lírico na produção poética. Esse é um tema caro à crítica de poesia que pode ser encontrado no bojo das reflexóes em torno da necessidade de revisâo da produçăo poética brasileira. O campo teórico mais amplo, do qual nossa leitura também se serve e toma como ponto de partida, diz respeito a uma constante reconfiguraçâo do sujeito lírico, marca profunda de uma das linhas de força mais significativas da poesia brasileira contemporânea, isto é, a expançăo dos limites entre os tempos da lírica moderna e contemporânea.

No ínterim desse diálogo, uma das chaves de leitura é enfrentar um problema que se situa no cruzamento, que se coloca como um espaço dúbio e deslizante, entre a tradiçấo da modernidade, tendo como uma de suas linhas de força a liberaçáo da expressăo lírica da mímesis do mundo, da imitaçăo da natureza e do caráter humano nos seus sentidos tradicionais, e a crítica do contemporâneo, que reforça a expansâo dos sentidos de uma consciência crítica como um devir da condiçâo da criaçăo poética.

Esse percurso crítico já fora lido e pontuado por estudiosos da poesia brasileira contemporânea. Mencionamos alguns exemplos, sem a pretensăo de esgotamento, com a finalidade de situar melhor o estado da questăo. A crítica Viviana Bosi, em um trabalho sobre a poesia de Rubens Rodrigues Torres Filho, Francisco Alvim e Sebastiăo Uchoa Leite situa o problema do sujeito na poesia brasileira no intervalo de uma construçâo lírica que nega a própria condiçăo si, ou seja, há um "tipo de năo-relaçăo consigo mesmo e com o outro" e ao mesmo tempo uma negaçăo do desejo de exteriorizar-se, uma projeçâo para fora que pudesse refletir uma "íntima alteridade". O estranhamento no modo como a voz lírica se projeta por esses poetas é percebido por Viviana Bosi como a evidência do que ela chama de "consciência do alheamento", um processo que aponta para o amadurecimento crítico do modo a partir do qual os poetas contemporâneos passaram a compreender a condiçăo do sujeito na poesia. (BOSI, 2013, p. 89-90).

Essa proposta de leitura toma como pretexto crítico a ideia de que o retorno ao problema do sujeito na poesia volta com maior fôlego a partir do desejo de ruptura com os ideais concretistas, de modo que essa nova subjetividade lírica se afirma pela desconfiança em sua centralidade ou organicidade. Viviana Bosi compreende que esses poetas se situam em um lugar intermediário, "ocupam um lugar de passagem entre o moderno e o contemporâneo", o que provoca a compreensăo de um "reconhecimento lúcido de que parte de sua voz lírica foi convertida em coisa alheia". (BOSI, 2013, p. 91). É nessa chave que Viviana Bosi lê a presença de imagens que denunciam o estranhamento do eu voltado a si mesmo sob a condiçăo de terem se tornado coisas. 
De modo análogo, o professor e crítico Paulo Andrade, ao ler a poesia de Sebastiâo Uchoa Leite, vai propor uma análise a fim de observar como o projeto poético do referido escritor incorpora o que o crítico chama de "descentramento do eu lírico no processo de criaçăo" (ANDRADE, 2018, p. 29). Uchoa Leite, que também é lido por Viviana Bosi, é um poeta central nesse debate. O poema "Metassombro", presente na fase conhecida como a Antilogia (1972-1979), é sintomático para essa discussâo:

\author{
Metassombro \\ eu năo sou eu \\ nem o meu reflexo \\ especulo-me na meia sombra \\ que é meta de claridade \\ distorço-me de intermédio \\ estou fora de foco \\ atrás de minha voz \\ perdi todo o discurso \\ minha língua é ofídica \\ minha figura é a elipse \\ (UCHOA LEITE, 2015, p. 110)
}

O poema de Uchoa Leite anuncia-se pela via paradoxal que rompe com o princípio da năo contradiçấo. Desde o título, há o anúncio de um oximoro do reconhecimento de uma identidade que năo é ela própria. Chama a atençâo a imagem especular que persegue todo o poema, surgida pela presença do reflexo, o que anunciaria uma identidade reconhecível do eu, mas que se nega desde o início. É na ambiguidade de "especulo-me", que tanto pode ensejar a noçăo do espelhamento quanto da reflexăo, que notamos, de um lado, um olhar que se direciona para dentro, em busca de uma identidade cindida, perdida, e de outro, um olhar externo que vê sua imagem diante do espelho - speculum, como lembra Paulo Andrade (2018) ao retomar o termo latino.

É notável que entre uma possibilidade e outra o poema se constrói no meio do caminho, na rasgadura da imagem, na "meia sombra", a "meta claridade", o "intermédio" e o que está "fora de foco". Temos um sujeito que năo se dá e năo se completa como ser, nem pela imagem especular nem pela consciência de si ou de sua identidade. $O$ resultado desse percurso que se dá no meio do caminho é a transfiguraçăo do sujeito, que se vê "ofídico" e "elíptico". O movimento do poema, igualmente serpenteante, garante a fuga da ideia de um sujeito pautado pela razăo e direciona-se para a transfiguraçăo em uma outra condiçáo de ser.

Eduardo Veras, por sua vez, observa esse mesmo movimento na poesia de Paulo Henriques Britto, ao destacar a imagem do "panda desgracioso", do poema "História natural":

Primeira pessoa do singular:

a forma exata da sombra difusa.

Quem fala sou sempre eu a falar.

A máscara é sempre de quem a usa. 


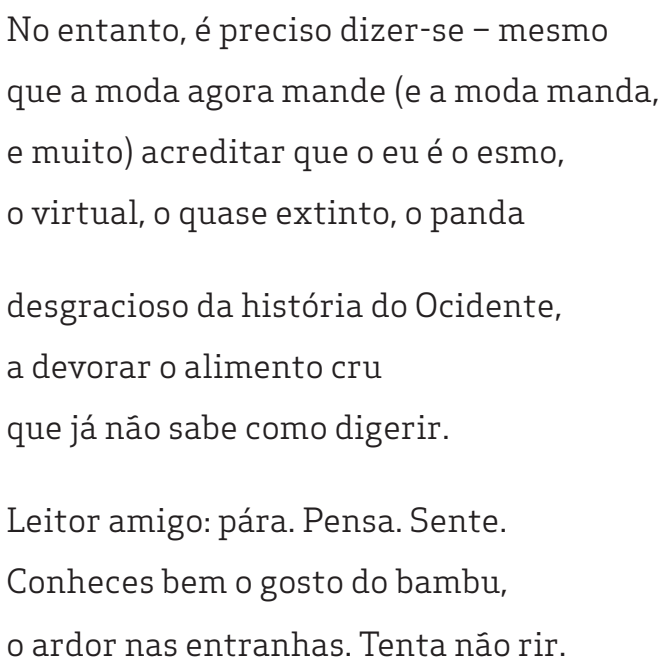

(BRITTO, 1997, p. 83)

A subjetividade é o tema central do poema de Britto. Eduardo Veras (2018, p. 283), ao pensar os modos pelos quais essa subjetividade se dá na obra de Britto, chama a atençấo para o caráter "difuso" do eu, o qual, mesmo sob a suspeita de náo poder dizer, nâo hesita em afirmar a necessidade de "dizer-se". A afirmaçăo do sujeito se dá, no entanto, em forma de oposiçăo à "moda" literária que prega a prevalência da ficcionalidade do sujeito, como se nota na segunda estrofe do soneto. Este modo de se afirmar, assim como em Uchoa Leite, assume uma via alternativa. No caso de Paulo Henriques Britto, o sujeito se mostra em seu caráter de "sombra", isto é, "de elemento fugidio e avesso à formalizaçăo, mas principalmente como figura patética, 'desgraciosa', 'quase extinta' da 'história do Ocidente' (VERAS, 2018, p. 283). Desse modo, portanto, a poesia de Britto, e a questăo do sujeito, por consequência, parecem partir do caráter incontornável da subjetividade para se inscrever como tentativa de apreensăo linguística desse fenômeno essencialmente informe, como argumenta o crítico Eduardo Veras.

A ideia da precedência da subjetividade na poética de Britto, ainda em diálogo com a leitura de Veras (2018, p. 284), fica mais evidente se considerarmos que a imagem central do "panda desgracioso" reintroduz no universo poético "um elemento cômico", "associado à natureza infra-humana", de modo que o 'eu' se apresenta como uma espécie descrita pela "História natural", isto é, "como uma entidade biológica, um exemplar do reino animal". Notamos nesse ponto outro movimento de aparelhamento do sujeito com o extremamente outro, capaz de se anunciar no modo como se anuncia a própria poesia.

Nesses três casos percebe-se uma certa tendência na poesia brasileira na qual a obra da poeta aqui estudada pode, certamente, ser inserida, embora a faça de modo muito particular. Essa via de leitura segue o caminho já consagrado na crítica à obra oridiana, qual seja, a relaçâo com a filosofia. Pedro Duarte (2019, p. 107) destaca três movimentos a partir dos quais se pode "achar poesia na filosofia". O primeiro movimento propóe pensar "a identificaçăo de que a filosofia fala por metáforas e imagens, nâo somente por conceitos". Nesse ponto, Duarte relembra as alegorias filosóficas como uma forma de pensamento, tais como a caverna de Platăo, o rio de Heráclito, por exemplo. A própria Orides Fontela, em texto-ensaio sobre sua relaçáo 
com a poesia, acena para esse aspecto considerando o pensamento filosófico como um exercício criativo:

A poesia, claro, năo apresenta provas: isto é tarefa para a filosofia. Mas os filósofos - os criativos mesmo - também partem de intuiçóes, e é a poesia que dá o que pensar. Que dizer dos incitantes fragmentos de Heráclito? Mistério religioso? Filosofia? Poesia? Tudo junto! E de Platăo, aliás também poeta? E de Heidegger - que confesso ter lido como poesia - que, afinal, acaba no poético, por tentar algo indizível? Há muita poesia na filosofia, sim. Năo poesia didática - como a dos pré-socráticos - mas poesia como fonte que incita e embriaga. (FONTELA, 1998, p. 14).

Para ampliar esse dado de que a filosofia também pensar por imagens e metáforas, isto é, um modo de pensamento que se expande para possibilidade do ato criativo, pensemos o segundo movimento proposto por Pedro Duarte: "o reconhecimento de que a filosofia também é sempre uma forma de linguagem na qual o pensamento é expresso, assim como a poesia". Os filósofos destacados por Duarte, nesse ponto, sáo Walter Benjamin e Gilles Deleuze, os quais apresentam, cada a sua maneira, uma forma específica de organizaçăo da linguagem e da própria obra. O caso de Walter Benjamin é bastante singular para esse movimento, sobretudo pelo caráter fragmentário de sua escrita. Theodor Adorno tem um texto seminal - "o ensaio como forma" (1986) - no qual assinala a necessidade de examinar a escrita benjaminiana como forma, isto é, como um modo de escrita que combina uma formaçăo teórica e crítica com uma formaçăo estética e literária, tendo o fragmento como elemento de singularizaçấo de sua escrita.

O terceiro movimento de Duarte busca chamar atençăo para "o encontro da palavra nâo em seu uso habitual de comunicaçăo pragmática de funçôes e conteúdos, mas em estado livre, de nascimento, ou seja, de fonte e incitaçăo - que faz pensar e sentir simultaneamente". Este último movimento, sem colocá-lo como mais importante do que os outros, nos interessa, em particular. Há, nesse ponto, um contato com a filosofia da linguagem e também a abertura para se pensar a poesia da Orides Fontela como uma fala que se expande para a pluralidade, o que mantém como signo de sua poética a ambivalência da palavra.

A chave desse problema de linguagem, e o consequente modo de pensá-lo estética e filosoficamente, diz respeito à "persistência da exigência clássica da clareza ou da fidedignidade da poesia e com isso a convicçâo de que a linguagem, nesse caso poética, alcança formular em perfeiçâo o seu objeto" (OSAKABE, 2002, p. 98). A grade questâo trazida à tona por Osakabe, e, por extensâo, o modo como pensa a poesia de Orides Fontela, tem a ver com um processo de "inversâo de perspectiva", isto é, um processo radical de linguagem em que a "indizibilidade essencial desse objeto", ou a "impossibilidade de enformá-lo dentro da linguagem declarativa", se torna o elemento essencial para que a poesia "deixe de representar" (ou seja nomear) para aludir ou sugerir. Em síntese, trata-se de um processo no qual "o caráter radicalmente subjetivo dessa experiência, e sua natureza nâo racional, determinaria nâo apenas a aproximaçăo do sujeito com o em si (ou a essência) da coisa, mas também a aproximaçấo do em si do sujeito com o em si da coisa. (OSAKABE, 2002, p. 99).

Osakabe, ao ler a poesia de Orides Fontela, pontua o fato de que 
a palavra poética extrapola em muito a visăo da linguagem como representaçáo de algo que a antecede. Sim. A palavra poética é criadora de si mesma e a si mesma se consome porque, ao dizer-se, ela esvai-se na sua própria vitalidade. É condiçáo de sua própria precariedade. (OSAKABE, 2002, p. 102).

Há, nessa perspectiva, portanto, uma abertura radical para a alteridade, um movimento poético que força o sujeito para fora de si. O problema do sujeito lírico que se expande e se mostra fora de si é um tópico bastante complexo e que permeia a discussâo poética desde a modernidade, ao menos. Na famosa carta de Rimbaud a Paul Demeny, de 15 de maio de 1871, o processo de reconfiguraçâo do sujeito já aparece na afirmaçăo amplamente conhecida de que "Eu é um outro" (2008, p. 38). Essa imagem rimbaudiana, como explica Michel Collot (2018, p. 48), "é ter perdido o controle de seus movimentos interiores e, por isso, ser projetado para o exterior". Collot aponta para a poética de Rimbaud como uma experiência que se manifesta no salto para fora de si, e além, pressupóe uma verdadeira comunhăo com a natureza e com a própria linguagem, "carne sutil (...) que dá corpo ao pensamento [do sujeito lírico moderno], mas que permanece um corpo estranho" (COLLOT, 2018, p. 51).

Em um desdobramento da filosofia de Collot, seria possível pensar esse processo de vincular o sujeito fora si com a natureza ligado a um "pensamento-paisagem". A paisagem, nesse contexto, năo se reduz à representaçăo, nem a uma simples presença, mas se abre como força de pensamento cujo resultado será o do encontro entre o mundo e um ponto de vista; uma via interativa que leva o sujeito a pensar de outro modo. A poesia é um lugar privilegiado para refletir sobre essa interaçăo, sobretudo porque o pensamento-paisagem "implica um sujeito que náo reside mais em si", mas que por força do encontro e da interaçăo de seu ponto de vista e o mundo, ele "se abre ao fora"; uma experiência, portanto, que redefine a própria "subjetividade humana năo mais como uma substância autônoma, mas como relaçâo". (COLLOT, 2013, p.30). No poema "Ver", de Orides Fontela, é possível notar essa abertura:

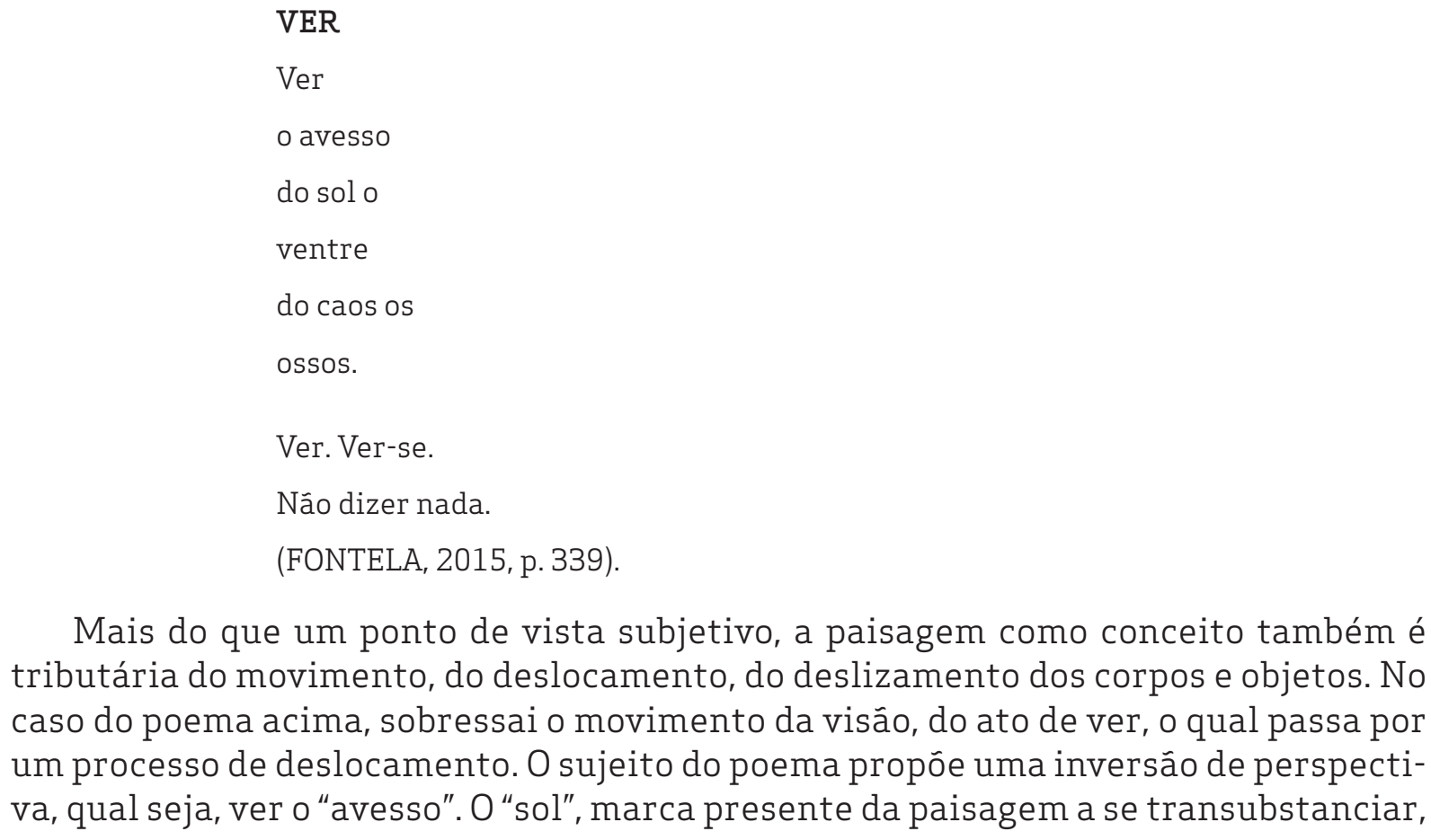

Mais do que um ponto de vista subjetivo, a paisagem como conceito também é tributária do movimento, do deslocamento, do deslizamento dos corpos e objetos. No caso do poema acima, sobressai o movimento da visăo, do ato de ver, o qual passa por um processo de deslocamento. O sujeito do poema propóe uma inversâo de perspectiva, qual seja, ver o "avesso". O "sol", marca presente da paisagem a se transubstanciar, 
é tomado por um ângulo de visăo desviante. Assim como Collot (2018, p. 63-64) afirmara ao ler Rimbaud, que "para "se fazer vidente", o poeta deve "perder a inteligência de suas visôes", podemos ler o poema de Orides na mesma clave, pois trata-se de um poema que invoca um sujeito cuja despretensâo com o racional e o desejo de "ver-se outro" permitem apontar para a reconfiguraçấo no modo como o sujeito se coloca.

A presença da paisagem como elemento que ocupa o lugar do sujeito - sobre este último nâo se pode "dizer nada", como se lê no poema de Orides - promove uma rasgadura no processo de identificaçáo do poema que nos oferece ao pensamento, ou nos faz pensar. Nos termos de Collot (2013, p. 12), "a paisagem propôe-nos entre outras coisas, um modelo para a invençáo de um outro tipo de racionalidade, que denomino pensamento-paisagem". No caso da poesia de Orides, o silêncio é uma via a partir da qual o sujeito se anula e a paisagem se anuncia como fonte de expressăo e pensamento. Como afirmara Marcos Lopes (2008, p. 126) sobre a poesia de Fontela, "o eu lírico empresta sua voz porque náo se trata de uma poesia de extraçăo romântica, obcecada com seu desejo de ver a si mesma, esquecendo-se de se deixar ver". É, ao contrário, uma poesia que se abre ao que está numa posiçấo imediatamente outra.

Diante desse contexto, é possível aventar a hipótese de que a poesia de Fontela toma, assumidamente, a proposta do "eu-mínimo", da metamorfose do sujeito em outros seres e coisas, através da linguagem como um projeto literário. A (re)configuraçâo do sujeito lírico em sua obra embaralha os dois polos anunciados por Osakbe, de modo que náo se distingue o ser da coisa, como se pretende observar pela análise do poema corpus deste ensaio.

\section{"O CARAMUJO" DE ORIDES FONTELA - TORNAR-SE OUTRO}

A poesia de Orides Fontela foi "descoberta" por um seu conterrâneo, Davi Arrigucci Jr., em um poema seu publicado em um jornal de Săo Joâo da Boa Vista, interior de Sâo Paulo. Com a aproximaçâo, ele a ajudou a organizar o primeiro livro da autora, Transposiçâo, de 1965. Seria o mesmo Arrigucci a fazer a ponte com o maior crítico literário do momento, quiçá de todo o século passado no Brasil, Antonio Candido, e com a própria Universidade de Săo Paulo, onde a poeta graduou-se em Filosofia.

Para Luís Dolhnikoff (2015), a poética de Orides acabou servindo de "títere" na luta surgida entre as vanguardas daquele momento, em especial o Concretismo, e os defensores da herança modernista, para os quais o verbovocovisual representaria, entre outros males, a "morte do verso". A poesia daquela jovem de pouco mais de vinte anos serviria náo só como um elemento catalisador ainda esperado pela academia, mas, principalmente, atenuaria os golpes dos "poetas de campos e espaços".

Ironicamente, a poesia de Orides é, por excelência, antilírica, coisal, como se costuma referir, por exemplo, à poesia de um Vasko Popa, poeta sérvio, ou, com um certo exagero na aproximaçâo, à de Joâo Cabral de Mello Neto. É a palavra, a lida com a linguagem, que aparece em primeiro plano, e năo o sujeito lírico, como veremos no poema a ser aqui analisado. Em suas poucas entrevistas, a autora declarava-se abertamente adepta da espontaneidade, no entanto, duas linhas se cruzam por baixo do que seria "apenas" inspiraçăo: em primeiro lugar, a profunda formaçâo filosófica, em especial durante a temporada na USP, que formou um profundo arcabouço de 
mitologias e conceitos, especialmente kantianos e heideggerianos; o segundo aspecto foi sua forte aproximaçáo com o budismo, que marcaria para sempre um toque oriental em muitos de seus textos. Nas palavras de Luís Dolhnikoff,

Mas se for de fato inevitável, ou necessário, aproximar sua poesia de alguma filosofia, é preciso pensar em Wittgenstein. Pois um dos temas mais caros a essa poesia é da relaçáo da palavra com o calar, com o calado, além daquela das palavras com as coisas e das coisas com o silêncio: a poesia é, seria ou deveria ser uma possibilidade de trânsito, de transporte entre tudo isso (daí o referido título de seu primeiro livro, Transposiçâo). (DOLHNIKOFF 2015, p. 12).

Esse domínio de forma e fundo, do jogo entre significante e significados, tornou a poeta celebrada no ciclo acadêmico, como já citado, no entanto, impossibilitou a popularidade que outros nomes da sua geraçăo possuíam. Soma-se a isso o caráter muitas vezes intempestivo, visceral e, por consequência, incompreendido da autora. Orides sofreria com o álcool, o despejo, a depressâo, a esquizofrenia e, no fim de apenas meio século de vida, morreria de tuberculose num sanatório público de Campos do Jordăo. Para além da vida, ou vida adentro, no entanto, dezenas de obras lançam cada vez mais luz sobre sua poesia: teses, traduçóes, artigos, antologias e, principalmente, leitores têm enfrentado essa esfinge que, uma vez encontrada, náo pode ser ignorada. Náo à toa a belíssima biografia escrita por Gustavo de Castro (2015) sobre a poeta ter como título "O Enigma Orides". Como se, no espelho do poema, ela sussurrasse, com meio riso: "Me decifra-te ou te devoro-me".

A leitura aqui proposta entende que há um ponto de fuga subjacente à singularidade poética da autora de Teia, a qual nos apresenta como uma de suas linhas de força o processo de reconfiguraçăo do sujeito lírico. Se antes o poético era delineado por uma "certa transcendência permitida por um alto grau de autorreflexăo da poesia", o único caminho para a depuraçăo do poético era a techné. Revelava-se, entâo, o eu como verdade interior, visível e referencial; a sublimaçâo das sensaçôes e dos afetos como preceitos da ars poética; a depuraçâo metalinguística como desveladora das figuraçóes dos conflitos interiores como índice de profundidade estética (SILVA; MORAES, 2020, p. 43). Agora o poético, como pensado na obra de Orides, se dá no processo da transfiguraçăo do eu.

Em Políticas da escrita, Rancière (2017, p. 118) levanta a seguinte questăo: "năo será necessária uma nova forma da experiência política para emancipar o sujeito lírico do velho quadro poético-político?". Rancière situa o problema no sentido de romper com a concepçấo canônica da definiçâo do poético pautado pela distinçâo dos gêneros. A noçăo de emancipaçāo do sujeito lírico, como postulada por Ranciére (p. 118), está menos relacionada ao discurso já saturado de ruptura das regras caducas e de expressôes convencionais da poesia, e mais próxima da política ligada ao modo de dizer da poesia, isto é, de "liberar o Eu de certa política da escrita".

O Eu, na leitura do filósofo francês, é a grande marca do pendor lírico, colocado sob suspeiçăo na medida em que é visto como um corpo político, e nâo somente como uma personagem ativada para garantir o objeto e os meios do poema. A discussão, no entanto, náo é de agora. O grande paradigma enfrentado pela poesia moderna, por exemplo, já apontava para a tensâo entre a subjetividade da poesia lírica e o eu empírico, quando Mallarmé enuncia o "desaparecimento elocutório do poeta". 
A tradiçăo moderna a qual fazemos referência tem suas linhas de força localizadas em As flores do mal, de Baudelaire, ou mesmo desde as ideias de Novalis, já em fins do século XVIII, as quais elevam os limites da relaçăo entre poesia e pensamento, o que acentua o gesto autorreflexivo do fazer artístico a partir do qual a consciência crítica serve de ponto de partida da expressăo estética. É nesse ponto que Rancière (2017, p. 121) vai pensar o lirismo moderno "[...] nâo como uma experiência de si ou uma descoberta da natureza ou da sensibilidade, mas como uma nova experiência política do sensível ou experiência sensível do político".

Roberto Zular (2009, p. 393), em diálogo com o pensamento de Rancière, também acentua o processo de transformaçáo da subjetividade na poesia. Para o autor, náo se trata, portanto, "[...] apenas de afirmar o lugar de uma voz, mas de mudar o próprio espaço em que essa voz é determinada ética e politicamente pelas vozes que a atravessam". Nesse ponto, o crítico leva em conta, à luz de Rancière, o lugar da experiência poética como meio privilegiado da partilha entre as vozes, levando em conta que toda voz se faz múltipla por se constituir em um espaço de relaçăo plural. Esse movimento de translaçáo da dicçáo poética nos coloca diante de

[...] outros funcionamentos da voz que a abrem a um movimento incessante de transformaçôes e possibilidades. Sáo vozes que assumindo o pivoteamento realizam a partir dele um outro modo de produçăo do sentido, uma outra ética da voz (a qual, claro, passa por uma ética da escuta que lhe é constitutiva) e uma possibilidade de emergência do político com a invençâo de novos corpos coletivos e agências sociais. (ZULAR, 2019, p. 393).

Nesses termos, pensar a reconfiguraçăo do sujeito lírico da poesia de Orides é tomar a palavra como um elemento oscilante, que se dá no jogo filosófico da linguagem. Rancière (2017, p. 121-122) utiliza o termo "acompanhamento" para pensar as possibilidades de formular a questăo. A primeira maneira de entender esse problema passa pelo modo de pensar que "a questăo do lirismo emerge quando a poesia toma consciência de si mesma como sendo o ato de se acompanhar, como a coextensividade do Eu a seu dito"; mas também esse Eu, que num segundo momento, "acompanha o poema e se produz como ressonância de seu ato é uma subjetividade" que percorre um certo território, o que faz coincidir nesse trajeto palavras, visōes, e nesse processo "uma relaçăo com o nós da comunidade".

Nesse sentido, a grande força de deslocamento da poesia de Orides pode ser observada em uma nova retomada do papel do sujeito poético. Todavia, o adensamento crítico de tomada de consciência e de acompanhamento, no sentido que Rancière pondera, só nos parece possível quando confrontarmos, efetivamente, a tradiçăo dita clássica.

A saída para o enfrentamento desse problema está na associaçăo dos modos de pensar "ocidental" e "oriental" que convivem, simultaneamente, na obra de Fontela. Tomar a ideia do sensível-político da poesia moderna, como destacou Rancière (2017, p. 123), pode ser uma via possível de entender que "[...] o dispositivo moderno da representaçăo política se baseia numa figuraçăo nâo representativa que a precede, numa visibilidade imediata do sensível". Aqui é possível observar o ponto de ultrapassagem de uma noçăo da relaçâo poético-política como aquela da "verdade" da enunciaçấo vinculada à qualidade do representado. O sujeito assume o perfil de 
corpo que se junta à noçăo da intercorporeidade, noçăo de Merleau-Ponty ${ }^{3}$, o qual, para pensarmos junto à Michel Collot,

[...] se comunica com a carne do mundo, abraçando-a e sendo por ela abraçado. Ele abre um horizonte que o engloba e o ultrapassa. Ele é, simultaneamente, vidente e visível, sujeito de sua visăo e sujeito à visăo do outro, corpo próprio e, entretanto, impróprio, [...] que fundamenta a intersubjetividade que se desdobra na palavra, ela mesma, um gesto do corpo. O sujeito náo pode se exprimir senáo através dessa carne sutil que é a linguagem, doadora de corpo a seu pensamento, mas que permanece um corpo estrangeiro (COLLOT, 2004, p. 167).

Na poesia oridiana, a linguagem assume-se como fuga, como silêncio, e ocupa lugar do corpo para que haja outros meios para que o sujeito se expresse. Em seu artigo no livro Poesia e Filosofia - Homenagem a Orides Fontela, intitulado "Ontologias: sobre as naturezas na poesia de Orides Fontela", Renata Sammer chama atençăo para o caráter "năo-humano" do sujeito figurado, transposto, de vários poemas da autora:

Săo títulos de seus poemas: "Rosa”, “Caramujo", “Girassol", “Fera", “Pássaro", “Gato", Cisne", "Centauro", "Peixe", [...]. O eu-mínimo, que caracteriza a poética de Orides, cede espaço a poemas que emergem de outras peles - animais e vegetais -, que exploram perspectivas humanas e náo-humanas (SAMMER 2018, p. 78).

Essa metamorfose aproxima a poética de Orides da chamada poesia coisal, de natureza náo anti-lírica, mas sem dúvida afastada da tradiçáo confessional típica de nossa história literária. Revela, em um de seus versos: "entre metamorfoses, superar-se". Em outro, "Alta agonia é ser, difícil prova". Entăo, que fazer senăo metamorfosear-se, através da linguagem, em outros seres e coisas? Metaformose. E dessa forma (o que novamente aproxima a autora do zen-budismo), compreender o mundo, o tempo e as coisas pela perspectiva do devir, ou, como diria Nietsche, na "transvaloraçáo de todos os valores", em que nâo se ocupa mais o espaço ontológico, sempre em guerra em ser e nâo ser, bem e mal, sim e năo, corpo e deus. É nessa chave que lemos o poema "Caramujo", a seguir:

\author{
CARAMUJO \\ A superfície \\ suave convexa \\ nâo revela seu dentro: \\ apenas brilha. \\ A entrada \\ estreita abóbada \\ é sóbria sombria \\ gruta.
}

3 Anoçăodeintercorporeidade, para Merleau-Ponty,surgenumprocessodetransformaçâointernanopróprio pensamento, desde a noçáo de intersubjetividade até ao que formulou como intercorporeidade, isto é, uma possibilidade radical de compreensâo da relaçáo entre o eu e o outro. O percurso de desenvolvimento desse conceito pode ser observado nos textos $O$ filósofo e sua sombra, publicado em Signes (1960) e considerado fundamental para se compreender a passagem entre as concepçōes desenvolvidas em a Fenomenologia da Percepçâo (1945) e em O Visível e o Invisível (publicado postumamente em 1964). 


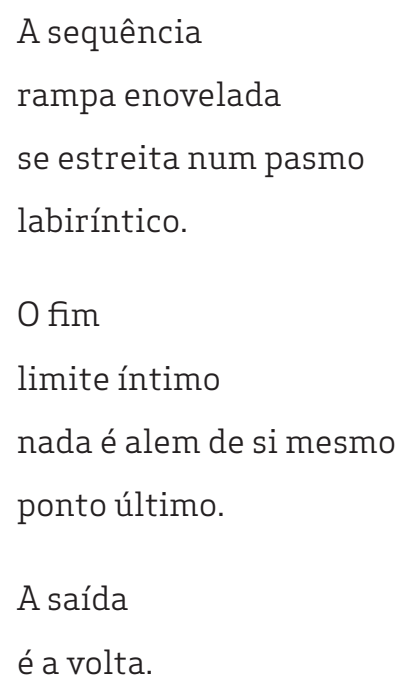

(FONTELA, 2015, p. 59)

Se somos, como defende Camus, "máquinas fazedoras de sentido em um mundo absurdo", é no mínimo lúdico pensar na forma como o objeto "caramujo" seria tratado, em linguagem literária, năo apenas por autores diferentes, mas de tempos diferentes, como tăo bem discute Benedito Nunes num ensaio sobre o tema, contido no livro "Palavras da Crítica: Tendências e Conceitos no Estudo da Literatura" (1992), organizado pelo Professor José Luís Jobim. Que soneto escreveria Alberto de Oliveira com o objeto provavelmente à sua frente, sobre a mesa? Que poema transmetafórico nos desenrolaria uma infância inventada em um caracol de Manoel de Barros? Que metafonia visual Augusto de Campos ou Arnaldo Antunes tirariam o caracol do mundo em 3d?

Vale trazer à tona, diante deste jogo, as palavras de Octavio Paz: "A poesia năo é a soma de todos os poemas. Cada criaçăo poética é uma unidade autossuficente. A parte é o todo. Cada poema é único, irredutível e inigualável" (PAZ, 1967). Neste sentido, a noçấo de "estilo de época" é esgarçada, perde sua intençăo de uma história da literatura, aproximando-se bem mais do que Deleuze e Guatarri denominam geografia do pensamento. Vejamos entâo algumas possibilidades de diálogo com a forma fonteliana de fazer o caramujo.

Como já dito anteriormente, na maioria dos poemas de Orides o eu-lírico cede espaço ao objeto: é a coisa que interessa, e o interesse do autor é aproximar o poema da coisa: năo apenas dizer a coisa, mas fazer com que o poema dela se apodere ou por ela se deixe impregnar. O poema é nitidamente construído como um roteiro, um mapa, um mergulho dirigido texto adentro: os substantivos que abrem cada uma das cinco estrofes desempenham esse papel: a superfície, a entrada, a sequência, o fim, a saída. O leitor é assim conduzido, mesmo sem convite expresso, a penetrar no casulo ao penetrar no texto. Por falta de conceito mais exato, podemos chamar a isto uma "sinestesia do movimento", porque os sentidos vâo sendo convocados conforme o mergulho/leitura acontece. Mas vamos por partes, como quis a poeta.

A superfície, convexa, nada revela, "apenas brilha", como uma concha, um vaso esmaltado, a superfície do lago. Há aqui um paradoxo: ora, o que brilha tende a revelar, năo ocultar. Na segunda estrofe, a antítese revela a esfinge: a abóbada é estreita, sóbria 
e sombria, revelando ser o caramujo um ser dúbio. Em seu livro já clássico, “O Ser e o Tempo da Poesia", Alfredo Bosi alerta: "Aparecendo como um todo finito e simultâneo, a imagem parece alinhar-se entre os fenômenos estáticos, já feitos, per-feitos, no sentido etimológico do termo. Será assim, desde que năo esqueçamos que o estático se compōe de forças diferentes em equilíbrio." (BOSI, 2009). Curiosamente, é na segunda estrofe que aparecem as primeiras metáforas para o caramujo: abóbada estreita e gruta sombria. Sigamos.

É na terceira estrofe, no centro do poema e do próprio caramujo, que a linguagem (e o leitor) escorregam na rampa, no novelo, o que faz emergir a metáfora central do texto: o labirinto. E sim, o labirinto é circular. Os labirintos que Orides Fontela carrega sáo sempre circulares, isto devido ao fato já mencionado de sua formaçăo ao mesmo tempo clássica/ocidental e clássica/oriental. O labirinto construído pelo Rei Minos é circular, assim como tantos outros labirintos gregos. E o budismo tem como traduçáo icônica do universo, em qualquer aspecto, o Tao, em que Ying e Yang enovelam-se. Confúcio e Nietzsche teriam uma conversa no mínimo curiosa sobre a circularidade e o eterno retorno.

A penúltima estrofe do poema nos apresenta o fim, náo do poema ainda, mas da própria imagem do que agora é mais que um caramujo. A sonoridade entre os vocábulos limite/íntimo/último constroem quase um eco daquilo de onde só se pode voltar, porque já se chegou ao limiar. E a última estrofe, dístico cristalino, nos oferece como que um fio de Ariadne, permitindo que a circularidade se complete, e năo há como nâo lembrar do Nó de Moebius, em que entrada e saída, dentro e fora, positivo e negativo, claro e escuro se completam, ao invés de confundir.

Em suma, talvez se possa dizer que este poema năo tenta descrever um caramujo, mas tornar-se, ele próprio, um labirinto tal qual, por força e maestria da metalinguagem utilizada no fazer poético. E se assim o compreendemos, a imagem do labirinto expande-se: o ventre, o nascer/morrer, os ciclos todos da natureza, o que ainda chamamos consciência humana, e especialmente a própria linguagem, labiríntica por essência, tecida entre os signos e os silêncios. O Caramujo de Orides é o próprio mundo. 


\section{REFERÊNCIAS}

ADORNO, Theodor. O ensaio como forma. In: COHEN, Gabriel (org.). Sociologia. Săo Paulo: Ática, 1986.

ANDRADE, Paulo. O olhar crí(p)tico na poesia de Sebastiăo Uchoa Leite. In: Alianças \& Rupturas: ensaios sobre a poesia contemporânea. Cotia, Săo Paulo: Editora Cajuína, 2018, p. 29-46.

BOSI, Alfredo. Alfredo Bosi, 0 Ser e o Tempo da Poesia. 8. Ed. Săo Paulo: Companhia das Letras, 2009.

BOSI, Viviana. O sujeito pedra: tornar-se coisa. In: RUFINONI, Simone R. (org.); REDONDO, Tercio (org.). Caminhos da lírica brasileira contemporânea: ensaios. Săo Paulo: Nankin, 2013, p. 89-107.

BRITTO, Paulo Henriques. Trovar Claro. Săo Paulo: Companhia das Letras, 1997.

CASTRO, Gustavo de. 0 Enigma Orides. 1. Ed. Sâo Paulo: Hedra, 2015.

COLLOT, Michael. O sujeito lírico fora de si. Traduçăo Alberto Pucheu. Revista Terceira Margem, Rio de Janeiro, n. 11, p. 175-177, 2004.

COLLOT, Michel. Poética e filosofia da paisagem. Rio de Janeiro: Oficina Raquel, 2013.

DOLHNIKOFF, Luís. Prefácio. In: FONTELA, Orides, Poesia Completa. Săo Paulo: Hedra, 2015.

COLLOT, Michel. A matéria-emoçăo. Trad. Patrícia Sousza Silva. Rio de Janeiro: Oficina Raquel, 2018.

DUARTE, Pedro. “Há muita poesia na filosofia, sim”. In: In: LAVELLE, Patrícia (org.) (et. al.). Poesia e Filosofia - Homenagem a Orides Fontela. 1 Ed. Săo Paulo: Relicário, 2018, p. 77-88. FONTELA, Orides. Poesia Completa. 1 Ed. Săo Paulo: Hedra, 2015.

FONTELA, Orides. Sobre poesia e filosofia um depoimento. In: PUCHEU, Alberto. Poesia e Filosofia. Belo Horizonte: Moinhos, 1998, p. 11-15.

LOPES, Marcos Aparecido. O canto e o silêncio na poética de Orides Fontela. Ipotesi, Juiz de Fora, v. 12, n. 2, p. 115 - 128, jul./dez. 2008.

OSAKABE, Haquira. O Corpo da Poesia. Notas para uma fenomenologia da poesia, segundo Orides Fontela. Remate de Males, n. 22, p. 97-109. Campinas: 2002.

PAZ, Octavio, 0 Arco e a Lira. 2 Ed. Săo Paulo: Cosac e Naify, 2012.

JOBIM, José Luís (Organizador), Palavras da Crítica. 1.Ed. Rio de Janeiro: Imago, 1992.

RANCIÈRE, Jacques. Políticas da escrita. Traduçâo Raquel Ramalhete et al. Săo Paulo: Editora 34, 2017.

SAMMER, Renata. Ontologias: sobre as naturezas na poesia de Orides Fontela. In: LAVELLE, Patrícia (org.) et. al. Poesia e Filosofia - Homenagem a Orides Fontela. 1 Ed. Săo Paulo: Relicário, 2018, p. 77-88. 
SILVA, Patrícia Pereira da.; MORAES, Paulo Eduardo Benites de. Das vozes insurgentes no movimento Poetry Slam à reexistência do slam das minas: a estética da poesia da quebrada pelas manas, monas e monstras. Revista Texto Poético, ISSN: 1808-5385, v. 16, n. 31, p. 40-63 jun./set. 2020.

UCHOA LEITE, Sebastiăo. Poesia Completa. Săo Paulo: Cosac Naify, 2015.

VERAS, Eduardo Horta Nassif. Cálculos no intestino da prosa: a poesia como corpo estranho em Paulo Henriques Britto. In: RIBEIRO, Gustavo Silveira (org.); PINHEIRO, Tiago Guilherme (org.); VERAS, Eduardo H. N. (org.). Poesia contemporânea: reconfiguraçóes do sensível. Belo Horizonte: Quixote+Do Editoras Associadas, 2018, p. 279-292.

ZULAR, Roberto. O núcleo pivotante da voz. Revista Cadernos de Traduçâo, Florianópolis, v. 39, n. esp., p. 372-402, 2019. 